\title{
Social Media as a Contemporary Communication Tool Between a City and its Users - a Theoretical Approach
}

\author{
Michał Sędkowski \\ (iD https://orcid.org/0000-0002-9646-0567 \\ University of Lodz \\ Faculty of International Relations and Political Studies \\ e-mail: michal.sedkowski@uni.lodz.pl
}

\begin{abstract}
Social media have become a standard in contemporary communication. That is especially true for business which jumped at the opportunity to connect with current and prospective customers allowing them to integrate with their favourite brands and products even further. This trend, however, seems to be absent in the public domain. Local authorities notice social media but attempt to use it in a one-to-many format, which is incompatible with the interactive nature of the new medium. Cities can strongly benefit from an active presence in the social sphere as it opens new paths to cogovernance and better communication.
\end{abstract}

Keywords: social media, urban governance, policy communication 


\section{Introduction}

Social media are constinually gaining new users wishing to engage in discussions on issues related to both private and business matters. The range of topics discussed can be freely modified depending on the needs. Private individuals, companies or public institutions have become a part of a global network that treats all entities equally. This is a new approach in the relationship between the sender and the recipient of content that brings about many benefits and unprecedented challenges. The added value of communication through social media is the ability to reach a specific recipient with your message, and the potential for receiving immediate feedback. Here, however, the question should be asked whether entities so far communicating through traditional means are prepared to enter the world of interactive communication. Local administration is an example of an entity that has hitherto contacted its users directly or through traditional media such as mail or telephone. New media remained out of its interest due to the need to maintain proper security procedures. The growing popularity of this form of communication among individuals forced some of the local authorities to enter the world of virtual media, where they have faced new challenges and possibilities. This paper aims to explore possible benefits and potential challenges that await cities that wish to incorporate social media into their communication matrix.

\section{Social media as a contemporary communication tool}

Before the emergence of social media, the Internet offered broad access to knowledge but did not give its users the opportunity to exchange opinions on a global scale. Communication took place in closed circles focused around a given issue. These communities constituted a kind of support groups for those involved, and the topics often went beyond the formal area of interest of an online forum or discussion group. The main problem was the scope of these undertakings, which on the scale of the Internet as a whole, were marginal. In this sense, social media was the answer to two basic human needs: the possibility of unhampered and free access to other people in the community and access to information that is important from their point of view (Kotler et al.). Social media are tools created to conduct discussions on any topic. Internet forums or discussion groups are usually formed for a specific purpose, e.g. to discuss current political events. Facebook or Twitter does not set such limits, allowing users to publish any content. Monica Patrut and Bogdan Patrut also indicate the need to create a private "infosphere" that 
is unique to each user. The infosphere is a stream of information flowing to the user from selected sources. In order for this information to be valuable, sources must be trustworthy from the point of view of the recipient concerned, and the best way to build such trust is from other people (Kotler et al.). The technique known as word-of-mouth is an effective tool for building the recipient's trust in a product, service or information. Research shows that consumers are much more likely to base their purchasing decisions based on the opinions of other consumers than on marketing materials. Social media are in a sense the answer to the needs described above.

Kaplan and Haenlein define social media as a group of Web 2.0 applications that allow users to create and share content online. By registering on a given social networking site, the user gets access to many sources of information which, through subscription, can provide desired information directly to one's profile (Garlicki and Mider). To be recognisable and easily find your friends or people with similar interests, you are encouraged to provide as much information about yourself as possible, including a profile picture. These are not required but recommended as they allow you to take full advantage of the functionality of the medium. This requirement to a certain extent increases the degree of user identification with the profile, which positively affects the substantive level of published materials (Bishop). A false sense of anonymity means that users put much less weight on the published content because they believe that it is impossible to connect the author to a specific statement. Emotions start to play an important role, which often leads to conflicts. The necessity to provide your data forces the user to think about what content they want to be associated with by others. In addition to access to information sources, users gain the ability to connect to groups not limited by geographical coverage, allowing them to discuss any topic with people from around the world. What is most important is the fact that all discussions are public and are usually observed by more than one person. Thus, each user is to a certain extent a moderator of a given discussion and can verify the veracity of the presented arguments. Each user can start a discussion on any topic as long as it can arouse sufficient interest among other users. In this sense, both the individual and the company or brand have similar tools to start and moderate discussions. Thus, everyone who wants to take part in a conversation on a given subject must perform a similar set of activities. In this way, the barrier associated with the need to exit the comfort zone of the recipient disappears, which is typical for communication with broadcasters associated with traditional media (Sloan, Quan-Haase). 


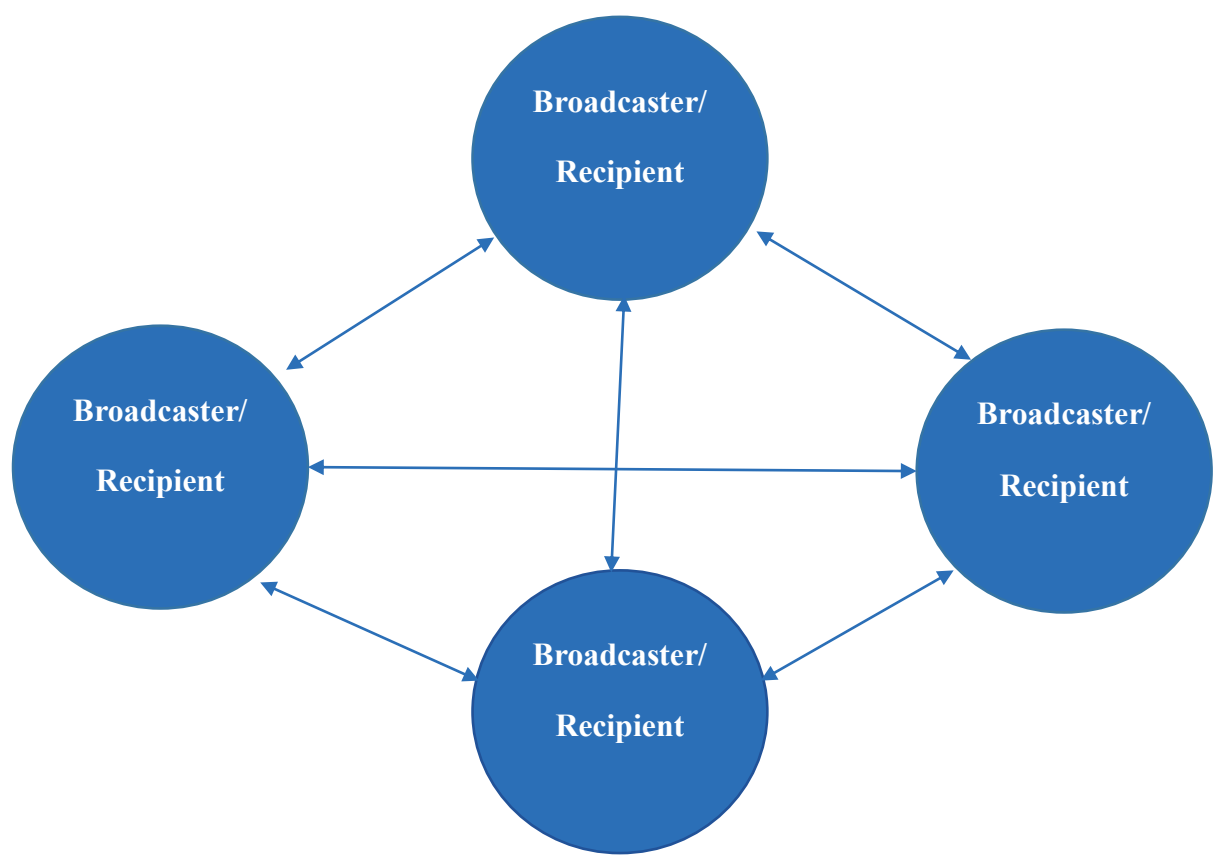

Figure 1. Social media communication model

Social media blur the distinction between broadcasters (creators) and content recipients. Users within a given social platform gain access to a range of tools that allow them to easily create new content, post comments and rate existing threads. Theoretically speaking, each post can become a contribution to a fervent discussion, where supporters and opponents will clash with arguments (Dobek-Ostrowska and Garlicki). The discussion then begins a life of its own, which can be considered an advantage as well as a disadvantage depending on the perspective. Czaplicka emphasises that this readiness to discuss every topic can cause a severe crisis that may have far-reaching consequences for a given entity or brand. In the definition of Kaplan and Haenlein mentioned earlier, the aspect of sharing content is emphasized. Each new piece of content is automatically visible to other users of the social network, which is an incentive to forward the message further. If the message is positive, it might be reinforced by others, while negative posts tend to gather much more attention and are automatically amplified. This process is a significant differentiator in comparison to traditional media. Social media enable instant communication of everyone with equal rights, which allows a single user to easily interact with even the largest companies or public entities like cities or local governments. What is more, the question posed by a single user is visible to a substantial group of users, hence ignoring it might cause tangible consequences. The strength of social media comes from built-in mechanisms, making it easier for users to connect 
to groups and support each other in disputes with large entities that have previously had most of the assets on their side. Users have discovered that there is a strength in the numbers that is difficult to ignore (Bakshy et al.).

\section{Local governments and social media - chances and threats}

Local self-governments have noticed the growing interest in this new communication method and attempted to meet the expectations of potential recipients. It is important to understand that unlike traditional media, Internet communication channels are interactive in nature; each communication tool has its own specific character and should be used accordingly.

Table 1. Potential use cases of Internet communication tools from the local government perspective

\begin{tabular}{|l|l|}
\hline \multicolumn{1}{|c|}{ Internet tool } & \multicolumn{1}{c|}{ Potential use case } \\
\hline Website & $\begin{array}{l}\text { - basic information about the unit } \\
\text { - information about current activities }\end{array}$ \\
\hline E-mail & $\begin{array}{l}\text { - fast and convenient way of reaching a particular audience } \\
- \text { can be used to create other tools like discussion groups } \\
\text { or newsletters }\end{array}$ \\
\hline Discussion group & - exchange of information and ideas between users \\
\hline Social media & $\begin{array}{l}\text { - current information streams } \\
\text { - other }\end{array}$ \\
\hline Blog & - analysis and comments on current events \\
\hline
\end{tabular}

Source: Author's own work based on: Rafał Guzowski, Administracja publiczna w mediach społecznościowych.

The summary presented in Table 1 indicates the basic problem faced by public entities wishing to start their presence in social media. Websites or information sent directly to specific recipients via email are strictly regulated by European law; the remaining tools function somewhat beyond its framework. It should be stated clearly that it is not forbidden or contraindicated, but that their place on the communication map of a public office is undefined. Rafał Guzowski rightly points out that officials are invited by Internet users to a completely different world: the world of social media. The emphasis on the presence of these entities comes from the stakeholders themselves who, having received a new tool, began to exchange opinions also on topics closely related to what is happening in their local environment. Social media is a universal and easily accessible medium, where everyone is a creator and a recipient of content at the same time. In the case of websites, tools 
related to e-mail, blogs or even discussion groups, it is the public entity as the owner (administrator) of a given channel that has full control over the published content and indirectly over the feedback from the recipients. In the case of social networks, such control is not feasible. Of course, in the technical sense, each social network gives the profile administrator the ability to manage access to specific content, or to block users from expressing their views or even accessing the entire profile as a whole. The problem arises owing to the very nature of social networks which put emphasis on public and collective communication. Each new content published on the official profile of the institution, including comments and comments of users, is automatically sent to all subscribers and available in the search results. At the time of uploading new content, it is automatically sent to all these people and, to put it precisely, it is inserted into their profiles. If for some reason the administrator decides to delete this content, it would be noted by users almost immediately. The situation is similar in terms of deleting comments or blocking users. This means that the public entity has much less control over the flow of information and ongoing discussions. As emphasised by Monarcha-Matlak (2008), one of the responsibilities of a public entity is to ensure that the information published is up-to-date and accurate. In the case of communication channels, where the entity is the only sender of a message such as a website, newsletter or e-mail, the published content is subject to full control. Social media put the institution and the user on a level playing field; therefore no party has complete control. It is possible to implement a mechanism forcing the message to be approved by the administrators before it is visible to the public, but it is a solution that requires a lot of additional management on the public office's part. Moreover, the users might consider the said control system as a form of censorship, which could negatively affect the image of a public entity.

As already mentioned, social media is based on content created by the users themselves who share their thoughts and opinions. Cities are trying to enter this trend by publishing information about current events. These posts are usually provided with colourful graphics or photographs illustrating a particular event or object to which the post refers. As a result, each profile subscriber receives daily the latest information about what is happening in the city and several pictures illustrating the city landscape. However, this approach does not fully exploit the possibilities of social media, which are interactive in nature. In this case, there is a passive transfer of content that does not translate into user involvement. The causes of this phenomenon may be multiple:

- Guzowski argues that public administration officials now face a new communication landscape - social media is an important communication channel for many people and presence within this medium is a necessity

- users are not interested in the presence of public authorities in social media. Due to the slow process of entering into the sphere of new media by public 
entities, the users simply do not expect interesting content from official city profiles, hence low involvement on their part

- there is a lack of resources on the side of local authorities, necessary for effective use of the new medium. Czaplicka emphasises that social media require that constant overwatch of what is happening on the profile. In other words, a person or group of people is required to constantly monitor city profiles and intervene when needed. Another challenge is creating enough interesting content to gain and retain the attention of users

- local authorities have concerns about the danger of a crisis, understood as an uncontrolled influx of negative opinions on the profile concerning their plans or performance

- negative user experience from contacts with local authorities in the past. Previous contacts may have created barriers between users and local authorities that have permeated the virtual space.

To summarise, it should be said that local authorities and the entire public administration face the challenge of how to respond to the growing popularity of social media. On the one hand, there is an increasing number of users that would like to contact the public office through the Internet. On the other hand, there are legal and technical difficulties that prevent the provision of official services entirely through the Internet. These limitations give rise to frustrations on the part of the recipients who do not have full confidence in services provided electronically.

The specificity of social media is a separate issue. It is a very dynamic medium, which focuses on fast, open and often unstructured communication, which to some extent runs counter to the specificity of a public office. The office, as already mentioned, should ensure that the information published is up to date and true. Tomasz Piróg argues that efficient communication is important, but its accuracy is key. Speed and the dynamics of social media significantly hinder the ability to fully check every information prior to publishing. It is necessary to seek a compromise between speed and quality of the published materials. Social media are not just a temporary trend and should be slowly implemented into a communication strategy. At the moment their activity is informative: it is mainly current information and attractive photos from a given city that are published. However, there is a lack of interaction between the city (local authorities) and users. This may be due to the lack of competence on both sides and the resources necessary to conduct an effective dialogue. Never before has this type of communication been carried out, where both parties have the option of sending a message visible to all other users. Thus, it is necessary to develop principles of such communication through social media on the basis of negotiations between the parties involved. When one of the parties tries to impose its vision, the entire process will end in failure (Adamczuk, 2014). 
Another issue is lack of legal support for social media, which makes it difficult to implement them into an official communication matrix. This raises the question of whether legal regulations should be expected or whether the local administration should take the initiative. The concept of the New-Weberian State (Sześciło) by Christopher Pollitt and Geert Bouckaert assumes the restoration of the dominant role of the state, with particular emphasis on administrative law as an element protecting the relationship between the power and the citizen. Following this line of thinking, it should be stated that in the public domain there is no place for spontaneous publication of content, which is typical for new media. The state should regulate the status of social media and the scope of information provided by this channel. Here, however, the question should be asked whether the introduction of such regulation will not cause a drop in the interest of its users. The informal nature of communication through social media is their added value. On the other hand, the concept of New Public Management assumes that local authorities should take the initiative and become the manager striving to maximize achieved results by adapting to the new reality (Krynicka). The superior goal should be to increase communication efficiency. Legal regulations to use new tools are not necessary for this perspective. It is positive that cities try to meet the expectations of recipients in spite of these difficulties and try to appear in the social sphere of the global network.

\section{Facebook and Twitter as a communication platform for cities}

Facebook and Twitter dominate the social media market, offering unique characteristics for its users. Both platforms, however, are directed at other target groups, which to some extent, determines popularity among users. The first platform is multimedia-focused, while the other is information-driven. Cities are currently trying to promote themselves as a good place to live, work or study by communicating their offer to various interest groups. Social media are not a temporary trend, but a permanent element of the communication reality for many people who spend a lot of their time online every day. Thus, cities wanting to effectively communicate their offer and help residents in their everyday lives, must adapt to their communication expectations. Applying an analogy, a social media user can already expect information about the current promotion in his favourite sales network, current prices at his favourite petrol station and information about the launch of a new service by his favourite mobile network operator. Following this line of thinking, the user of social media is expecting from the city information about current cultural events, tourist attractions or changes in traffic organisation. There are already examples confirming that cities have attempted to use this method of communication and tried to provide their recipients with the latest information about what is happening 
within their boundaries. The city offers users a set of products and services aimed at satisfying their needs. Tadeusz Markowski defines a city product as a material or non-material element of the broadly understood functional and spatial structure of the city, which is subject to market exchange. It can be a specific place, location, civil service or a set of them, as well as an idea concerning, for example, urban development. The adoption of this perspective allows one to state that these products and services can be the subject of promotional activities by the city authorities. These activities can be carried out in both the real world and virtual reality. The goal is to build a positive image among users and to encourage them to use a given product or service (Sevin).

The issue can also be viewed from a political science perspective, where the product becomes an idea and the opportunity to participate in its creation and subsequent implementation. From the user's point of view, the opportunity to engage in urban policy development can be an added value. Many authors indicate that the possibility of co-deciding on the direction of local space development is an important element building positive relations between the city and its inhabitants (Markowski; Kowalczyk; Dzieniszewska-Naroska; Wilk). Cities can compete with each other by offering wide access to co-governing processes and real influence on the surrounding landscape. Social media allows the promotion of urban products to users living in a given city, as well as those outside it. In both cases, the goal is to encourage users to participate and try the city offer. On Facebook, users expect that they will be able to contact their favourite brand, product or service. Presented photos or videos of new products act as inspirations that aim to help users utilize their full potential. Facebook has become to some extent a portfolio for business, where you can present your products and services.

Cities carry out communication activities, presenting their offer using multimedia materials. It is also an element of positive image building strategy. Many authors emphasise (Czaplicka; Mistewicz; Guzowski) that the goal of a commercial entity should not be sales, but building an active and supportive community focused around this entity. This community is an ambassador who is interested in everything that happens around a given brand, recommends it to friends, or answers questions from other users. Stephen Dahl argues that social media is a very good tool for building a credible and positive image among clients (both current and potential). It is proven that users who have interacted with the brand using social media present a more favourable opinion about it and are more likely to forget about any problems. From the point of view of the brand, it is a tool that allows to monitor the mood among consumers, observe changing trends or even get inspiration for new products. From the point of view of the cities, the situation is similar, hence they can actively build their image using social media. Tomasz Domański indicates that cities should build their own brand based on their resources. This approach is now very strong in Polish science and many authors pick up the topic of 
effectively building a city brand based on territorial marketing tools (Florek et al.; Rogaska). Every city offers a set of products and services that impacts its image. This set of services is constantly changing through modernisation processes, broadly understood development and resource deterioration (negative process). Residents of cities utilise these resources, but they also co-create them through various types of co-decision and participation processes. If a commercial brand can build an active community around itself in social media, by allowing the users to take part in the process, it is also possible for cities. This is especially true for cities that are complex in nature and offer many overlapping products and services at the same time. From the residents' perspective, the possibility of direct contact with the city authorities and therefore the ability to influence the direction of future development can be a key selling point (Sobaci).

Potential benefits for both sides of the active community in social media, presented in Table 2:

Table 2. Potential benefits of an active community operating in social media

\begin{tabular}{|c|c|c|}
\hline $\begin{array}{c}\text { Possible social media } \\
\text { functions }\end{array}$ & $\begin{array}{c}\text { Potential benefits for } \\
\text { the city }\end{array}$ & $\begin{array}{c}\text { Potential benefits for } \\
\text { the user }\end{array}$ \\
\hline $\begin{array}{c}\text { Information about events } \\
\text { organised by the city }\end{array}$ & $\begin{array}{c}\text { Acquiring feedback from } \\
\text { the users }\end{array}$ & $\begin{array}{c}\text { Knowledge about current } \\
\text { events and possibility to } \\
\text { provide feedback }\end{array}$ \\
\hline $\begin{array}{c}\text { Information about } \\
\text { cultural and sports events } \\
\text { organised by stakeholders }\end{array}$ & $\begin{array}{c}\text { Presentation of the city } \\
\text { offer and positive image } \\
\text { building }\end{array}$ & $\begin{array}{c}\text { Knowledge about the city } \\
\text { offer regarding cultural and } \\
\text { sports events }\end{array}$ \\
\hline $\begin{array}{c}\text { Information about current } \\
\text { problems or accidents }\end{array}$ & $\begin{array}{c}\text { Positive city image } \\
\text { building and improving its } \\
\text { functionality }\end{array}$ & $\begin{array}{c}\text { Knowledge about current } \\
\text { problems and awareness } \\
\text { that the authorities are } \\
\text { monitoring the situation }\end{array}$ \\
\hline $\begin{array}{c}\text { Acquiring feedback from } \\
\text { the users }\end{array}$ & $\begin{array}{c}\text { Legitimisation of } \\
\text { undertaken activities }\end{array}$ & $\begin{array}{c}\text { Possibility of providing } \\
\text { feedback; feeling of } \\
\text { empowerment }\end{array}$ \\
\hline $\begin{array}{c}\text { Discussion about the } \\
\text { current situation in the } \\
\text { city/ plans for the future }\end{array}$ & $\begin{array}{c}\text { Building of social capital } \\
\text { Community and } \\
\text { co-responsibility building }\end{array}$ \\
\hline $\begin{array}{c}\text { Help for the users } \\
\text { regarding administrative } \\
\text { issues like how to get } \\
\text { something done in the city } \\
\text { office }\end{array}$ & $\begin{array}{c}\text { Increased effectiveness of } \\
\text { the office }\end{array}$ & $\begin{array}{c}\text { Decrease of time required } \\
\text { to complete an issue at } \\
\text { the office }\end{array}$ \\
\hline
\end{tabular}

Source: Author's work based on Guzowski (2015). Administracja publiczna... and Mistewicz (2014), Twitter.... 
It should be emphasised that the above list is only a small fraction of potential benefits for both parties. The condition for its implementation is the creation of an active community, that is one willing to discuss current issues related to the city itself. Clicking the Facebook Like button or posting on Twitter is important, but it does not give grounds to claim that the community is active in a conscious way.

In order to build a community around a profile in social media, it is necessary to create a profile and manage it in an attractive way, while maintaining appropriate standards (Kulczycki, Wendland). A very frequent mistake iss merging an account on Facebook with Twitter (or vice versa) which results in automatic copying of content from one to the other. Due to different requirements and limitations in the length of messages, the result are incomplete, often half-cut posts that simply lose their meaning. More importantly, it shows users of the merged service that they are less important to the broadcaster. This does not mean that information about the same event cannot be published on both portals. It is important to do it in a skilful manner, showing the described event from a slightly different perspective. The user must feel that the information is directed to them directly, which increases the likelihood of an interaction (Krzątała-Jaworska).

Table 3. Facebook and Twitter Compared

\begin{tabular}{|c|c|c|c|}
\hline Profile element & Facebook & Twitter & Remarks \\
\hline Social network & $\begin{array}{l}\text { Official profile; } \\
\text { graphics and } \\
\text { colours should } \\
\text { clearly be } \\
\text { connected with } \\
\text { the city. Official } \\
\text { contact should be } \\
\text { clearly provided }\end{array}$ & $\begin{array}{l}\text { Official profile; } \\
\text { name should } \\
\text { clearly indicate } \\
\text { which institution or } \\
\text { person the profile } \\
\text { represents. Contact } \\
\text { information must } \\
\text { be provided. }\end{array}$ & $\begin{array}{l}\text { If a city has an } \\
\text { official profile as } \\
\text { well as that of } \\
\text { its president or } \\
\text { spokesman, it is } \\
\text { worth pointing } \\
\text { out what kind of } \\
\text { information will be } \\
\text { published on any } \\
\text { given profile }\end{array}$ \\
\hline $\begin{array}{c}\text { Type of content } \\
\text { published }\end{array}$ & $\begin{array}{l}\text { Information about } \\
\text { upcoming events, } \\
\text { photos and videos } \\
\text { from past events; } \\
\text { photos and videos } \\
\text { illustrating changes } \\
\text { in the city }\end{array}$ & $\begin{array}{l}\text { Current } \\
\text { information } \\
\text { related to the city; } \\
\text { briefings on past } \\
\text { events }\end{array}$ & - \\
\hline $\begin{array}{c}\text { How the content is } \\
\text { presented }\end{array}$ & $\begin{array}{l}\text { Mutimedia-rich } \\
\text { content, minimal } \\
\text { text }\end{array}$ & $\begin{array}{l}\text { Brief information } \\
\text { with a link to the } \\
\text { full story }\end{array}$ & - \\
\hline
\end{tabular}


Table 3. (continue)

\begin{tabular}{|c|c|c|c|}
\hline Profile element & Facebook & Twitter & Remarks \\
\hline encouragement & $\begin{array}{c}\text { Multimedia- } \\
\text { based content } \\
\text { that promotes } \\
\text { discussion }\end{array}$ & $\begin{array}{c}\text { Question directed } \\
\text { at city influencers }\end{array}$ & $\begin{array}{c}\text { Influencers should } \\
\text { be identified by } \\
\text { the city }\end{array}$ \\
\hline Types of posts & $\begin{array}{c}\text { Information, } \\
\text { contests, content } \\
\text { published by users, } \\
\text { content published } \\
\text { by the city } \\
\text { stakeholders }\end{array}$ & $\begin{array}{c}\text { Information from } \\
\text { the city directly } \\
\text { and vital city } \\
\text { stakeholders }\end{array}$ & Important events \\
should be identified \\
Frequency of \\
publication
\end{tabular}

There are also some guidelines that can be considered universal:

- jargon and administration-typical vocabulary should be avoided. Messages should have a natural and spontaneuous character

- in the case of a polemic or dispute, do not use ad personam arguments, but try to explain the problem calmly

- do not delete any comments as long as they do not contradict the law or violate the basic principles of civilised communication. The falseness of the information contained in the comment is not a sufficient reason to delete it. The exception is when a person intentionally repeats false information to mislead others

- users should not be flooded with information but the information should be published based on a schedule. The exception is when something important happens in the city and users must be notified about it immediately

- the city should identify opinion leaders, social activists and city activists who can help distribute information and start discussions on a given topic. Often people who do not support city activities in a given area can be useful in building an active community (Gawroński).

The above guidelines do not guarantee that the city profile will be a place of active discussion, but it provides a solid foundation for building a community. It is important for the city to react quickly to what is happening on its profiles and leave no questions unanswered. Social media are based on the interaction between people and in a sense the city profile must have human characteristics, reflect the character of the city and the people managing it. For this reason, language misspellings or similar errors can be a positive thing as they might bring additional character to the profile. Every mistake should be corrected and the person who has spotted it thanked personally. In addition to publishing news related to your own posts, it 
is also a good idea to include profile subscribers in the content creation process. This will increase community involvement within the profile and its credibility in the eyes of recipients (Kim).

\section{Summary and further research opportunities}

The article characterised social media as an interactive medium that allows users to be involved in the processes of creating an interactive discussion platform. Agnieszka Smalec and Leszek Gracz argue that the local administration is currently facing the challenge of including new communication channels in its strategy of cooperation with users. It will allow broadening the scope of people involved in the co-management of the city and will enable the further implementation of the governance concept in public management (Podgórniak-Krzykacz). The effect will be a network of connections that allow one to communicate quickly and effectively with users; each of the social networks will play a different role in the process. Facebook is a potential starting point, where every user can start the process of getting to know others and engage in discussions about city issues. It is important that both parties communicate in a clear manner, in particular regarding mutual expectations and potential benefits of cooperation. Social media can definitely facilitate the start of a dialogue involving many people but engaging individual users who are important from the point of view of the city. It is a slow and lengthy process because it requires the construction of appropriate cooperation mechanisms, and the role of the initiator and curator of the process lies with the local authorities (Stanowicka; Szymkowiak and Scheibe; Gojny). It seems that the interest in electronic media to communicate with local administration is permanent; hence actions must be taken immediately to meet the expectations of recipients (Sommer and Michno). This is still a new, unexplored area of studies. Arguments presented in this paper are theoretical in nature and based on previous experiences of commercial entities. Further research is required to determine whether principles governing social media-based communication in the business sphere can be applied to the local administration. It is obvious that some changes will be necessary owing to law and transparency requirements governing any communication between a public office and a citizen. However, it does not mean that everything needs to be changed as experiences from the private sector have already shaped the communication habits of the masses. The true challenge that stands before every public office is how to fit into those habits and empower the users to be willing to participate in the co-governing process. This question will be one of the most important that researchers must try to answer in the near future. 


\section{Works Cited}

Adamczuk, J. “Media społecznościowe jako narzędzie kreowania wizerunku jednostek samorządowych na przykładzie samorządów lokalnych powiatu jeleniogórskiego.” Prace Naukowe Uniwersytetu Ekonomicznego we Wrocławiu 332 (2014): 189-199.

Bakshy, E., et al. "The Role of Social Networks in Information Diffusion." Proceedings of the 21st International Conference on World Wide Web, ACM (2012): 519-528.

Bishop, J. Examining the Concepts, Issues, and Implications of Internet Trolling. Hershey: IGI Global, 2013.

Czaplicka, M. Zarządzanie kryzysem w social media. Gliwice: Helion, 2013.

Dahl, S. Social Media Marketing: Theories and Applications. London: Sage, 2014.

Dobek-Ostrowska, B. and J. Garlicki. “The Impact of New Technologies on Political Communication. Western Patterns and the Case of Poland.” Political Communication in the Era of New Technologies. Eds. B. Dobek-Ostrowska and J. Garlicki, Frankfurt am Main: Peter Lang, 2013.

Domański, T. Marketing terytorialny: strategiczne wyzwania dla miast i regionów. Łódź: Centrum Badań i Studiów Francuskich. Instytut Studiów Międzynarodowych. Uniwersytet Łódzki, 1997.

Dzieniszewska-Naroska, K. Skuteczna komunikacja między władza lokalna a mieszkańcami za pośrednictwem Internetu. Instytut Spraw Publicznych, 2012.

Florek, M., et al. Wizerunek miasta: Od koncepcji do wdrożenia. Warszawa: Wolters Kluwer, 2009.

Garlicki, J., and D. Mider. "The Use of New Media in Election Campaigns in Poland." Political Communication in the Era of New Technologies. Eds. B. Dobek-Ostrowska and J. Garlicki, Frankfurt am Main: Peter Lang, 2013.

Gawroński, S. Komunikacja marketingowa samorządów terytorialnych. Rzeszów: BBConsult 2009.

Gojny, M. "Kierunki rozwoju zarządzania jednostką samorządu terytorialnego." Acta Universitatis Nicolai Copernici. Nauki Humanistyczno-Społeczne. Zarządzanie 43.1 (2016): 115-126.

Guzowski, R. Administracja publiczna $w$ mediach społecznościowych. Wrocław: Presscom, 2015.

Kaplan, A. M. and M. Haenlein. "Users of the World, Unite! The Challenges and Opportunities of Social Media." Business Horizons 53.1 (Jan-Feb 2010): 59-68.

Kim, C. M. Social Media Campaigns: Strategies for Public Relations and Marketing. London and New York: Routledge, 2016.

Kotler, P., et al. Marketing 3.0: From Products to Customers to the Human Spirit. Hoboken: John Wiley and Sons, 2010.

Kowalczyk, R. "Samorząd terytorialny jako uczestnik komunikacji społecznej." Przegląd Politologiczny 4 (2011): 21-36. 
Krynicka, H. Koncepcja Nowego Zarzadzania w Sektorze Publicznym. Prace Instytutu Prawa i Administracji PWSZ w Sulechowie, 2006. http://www.bibliotekacyfrowa. pl/Content/34636/014.pdf. Accessed 1 Sep 2016.

Krzątała-Jaworska, E. "Municipalities Mastering Social Networks. But For What?" Political Communication in the Era of New Technologies. Eds. B. Dobek-Ostrowska and J. Garlicki, Frankfurt am Main: Peter Lang, 2013, pp. 113-126.

Kulczycki E. and M. Wendland. Komunikologia. Teoria i praktyka komunikacji. Poznań: Wydawnictwo Naukowe Instytutu Filozofii UAM, 2012.

Markowski, T. "Marketing miasta." Marketing terytorialny. Ed. T. Markowski, „Studia” PAN KPZK, vol. CXII, Warszawa, 2002.

Monarcha-Matlak, A. Obowiazki administracji w komunikacji elektronicznej, Warszawa: Wolters Kluwer, 2008.

Patrut M. and B. Patrut, eds. Social Media in Higher Education: Teaching in Web 2.0. Hershey: Idea Group Inc (IGI), 2013.

Piróg, T. "Znaczenie komunikacji w zarządzaniu publicznym." Public Management 2013. Eds. W. Kieżun, J. Wołejszko and S. Sirko, Warszawa: Akademia Obrony Narodowej, 2013.

Podgórniak-Krzykacz, A. Local governance - czyli jak równoważyć zarzadzanie miastem, Uniwersytet Łódzki 2016, http://dspace.uni.lodz.pl/xmlui/ handle/11089/17990. Accessed 15 Dec 2016.

Rogaska, A. Promocja miasta elementem marketingu mix (Na przykładzie miasta Łomży). Promotor 2015.

Sevin, E. "Branding Cities in the Age of Social Media: A Comparative Assessment of Local Government Performance." Social Media and Local Governments: Theory and Practice. Ed. M.Z. Sobaci, Heidelberg, New York and London: Springer, 2016, pp. 301-320. https://doi.org/10.1007/978-3-319-17722-9_16

Sloan, L. and A. Quan-Haase. The SAGE Handbook of Social Media Research Methods, Thousand Oaks: SAGE, 2017.

Smalec, A. and L. Gracz. "Wykorzystanie mediów społecznościowych przez samorządy lokalne w procesie komunikacji społecznej." Prace Naukowe Uniwersytetu Ekonomicznego we Wrocławiu, 414 (2015): 180-191.

Sobaci, M. Z. "Social Media and Local Governments: An Overview." Social Media and Local Governments: Theory and Practice. Ed. M. Z. Sobaci, Heidelberg, New York and London: Springer, 2016, pp. 3-21. https://doi. org/10.1007/978-3-319-17722-9_16

Sommer, H. and J. Michno. "Szanse i zagrożenia społeczeństwa informacyjnego - wybrane aspekty." Kultura - Przemiany - Edukacja, Rzeszów: Wydawnictwo Uniwersytetu Rzeszowskiego, 2015, pp. 80-101.

Stanowicka, A. "Rola procesu komunikacji w budowaniu tożsamości miasta." Studia Miejskie 22 (2016): 155-166. 
Sześciło, D. Administracja neoweberowska: biurokracja 2.0?, Zakład Nauki Administracji, Wydział Prawa i Administracji, Uniwersytet Warszawski 2013. Accessed 1 Sep 2016. https://www.academia.edu/8196749/ Administracja_neoweberowska_biurokracja_2.0

Szymkowiak, A. and A. Scheibe. "Komunikacja samorządu terytorialnego ze społeczeństwem za pośrednictwem mediów społecznościowych." Collegium of Economic Analysis Annals 40 (2016): 299-312.

Wilk, S. "Perspektywy rozwoju elektronicznej administracji w województwie podkarpackim w opinii mieszkańców, przedsiębiorców i przedstawicieli administracji publicznej." Nierówności społeczne a wzrost gospodarczy 44.2 (2/2015): 354-371.

Michał Sędkowski, PhD - lectures in the Department of International Marketing and Retailing, University of Lodz. His scientific interests focus on new technologies, social media and mobile computing. His research aims to explore new possibilities offered by Internet communication tools such as social media and evaluate their impact on issues connected with private and public sector cooperation. His PhD dissertation tackled the problem of citizen participation in city management through social media in Poland. He is a member of the Polish Economic Association. 